\title{
Clinical audit to improve obstetric practice: What is the evidence?
}

Eugene Justine Kongnyuy'

Achille Kabore ${ }^{2}$

Pierre-Marie Tebeu ${ }^{3}$

'Liverpool School of Tropical Medicine, Liverpool, UK; ${ }^{2}$ Liverpool Associates in Tropical Health, Liverpool, UK; ${ }^{3}$ University of Yaoundé, Yaoundé, Cameroon
Correspondence: Eugene Justine Kongnyuy

Child and Reproductive Health Group, Liverpool School of Tropical Medicine, Liverpool, United Kingdom

Tel +44 I5I 7053705

Fax +44 I5I 7053329

Email kongnyuy@liverpool.ac.uk.
This article was published in the following Dove Press journal:

Clinical Audit

4 September 2009

Number of times this article has been viewed

Background: Clinical audit has been showed to improve professional practice from the providers' perspective. However, little is known about the effect of audit on the quality of care from clients' perspective.

Objective: To assess the effectiveness of criterion-based audit to improve obstetric care from both the health professionals' and clients' perspectives.

Methods: We conducted electronic searches of MEDLINE, EMBASE, and Cochrane Library in June 2009 for randomized controlled trials (RCTs) and before-and-after studies that assessed the effect of criterion-based audit on health outcomes or mothers/clients' perception of obstetric care.

Results: Twenty-three studies (one RCT and 22 before-and-after studies) involving 33,911 participants met our inclusion criteria. Only one of these studies assessed the effect of audit on quality of care from the mothers/clients' perspective. Ninety-six percent (22/23) of studies showed significant improvement in at least one standard measured. In general clinical audit led to moderate improvements in obstetric care and the effect of audit depended on baseline adherence to clinical standards.

Conclusions: Clinical audit is associated with moderate improvements in obstetric care from both the health professionals' and mothers/clients' perspectives. Audit has been used in obstetrics to improve quality mainly from one dimension, namely the health professionals' perspective. Midwives/doctors should consider the use of audit to improve quality of care from the mothers/clients' view.

Keywords: criterion-based audit, audit and feedback, obstetrics

\section{Introduction}

The term audit has been defined as "any summary of clinical performance of health care over a specified period of time". ${ }^{1}$ There are three main approaches to obstetric audit namely audit of deaths (maternal or perinatal), audit of severe morbidity (or near-miss), and audit of clinical practice. ${ }^{2}$ Deaths can be audited at the community level (eg, community-based maternal death review which is also called verbal autopsy), health facility level (eg, facility-based maternal death review), or regional/national level (eg, confidential enquiry into maternal deaths). Methods of analysis used in audit can be quantitative (eg, surveillance) or qualitative (eg, case review). Audit is based on criteria (or standards) of care which can be either implicit or explicit (eg, criterionbased audit). ${ }^{2}$

Criterion-based clinical audit has been defined as "a quality improvement process that seeks to improve patient care and outcomes through systematic review of care submit your manuscript | www.dovepress.com

Dovepress 
against explicit criteria and implementation of change. Aspects of structure, processes, and outcomes of care are selected and systematically evaluated against explicit criteria. Where indicated, changes are implemented at individual, team, or service level and further monitoring is used to confirm improvement in healthcare delivery". ${ }^{3}$ Criteria-based audit consists of five classic steps: establish standards of good practice, measure current practice, feedback findings and set local targets, implement changes in practice where indicated, and re-evaluate practice and feedback. ${ }^{2}$

A Cochrane systematic review showed that audit and feedback can bring about moderate improvements in professional practice. ${ }^{1}$ This review included 118 randomized controlled trials (RCTs) and only one of them assessed obstetric practice. The aim of the current review was to assess the effectiveness of criterion-based audit to improve quality of obstetric care as perceived by midwives/doctors in the one hand and quality as perceive by women/mothers on the other.

\section{Methods}

\section{Search strategy}

Electronic searches were conducted in the Cochrane Central Register of Controlled Trials (Cochrane Library Issue 1, 2009), MEDLINE (1966 to June 2009) and EMBASE (1980 to June 2009), by combining search terms for the intervention (audit, audit and feedback) and subject area (obstetric*, pregnancy, childbirth, midwifery). In addition, the electronic searches were supplemented by a hand search of specialist journals and reference list of identified studies. There were no language restrictions to the search.

\section{Inclusion criteria}

Our inclusion criteria were: (a) type of studies: (i) RCTs and non-RCTs that compared criteria-based audit with no intervention or with any intervention, (ii) criteria-based audit in which the results before and after feedback were compared, and (iii) criteria-based audit in which different types of feedbacks were compared. The term 'before-and-after studies' as used in this review refers to studies in which the authors compared the findings of an initial audit with a re-audit. (b) type of participants: Women who were either pregnant, in labor or in postpartum, and received care in a health care setting. We excluded studies on abortion or miscarriage. (c) type of interventions: criterion-based clinical audit defined as "an objective, systematic and critical analysis of the quality of health care against set criteria (standards) of best practice". ${ }^{2}$ Type of outcomes: objectively measured provider performance, health outcomes or women/mothers' perception of care in a health care setting.

\section{Statistical analysis}

We analyzed data using RevMan 4.2 software. For dichotomous data, study results were expressed as odds ratios (OR) with 95\% confidence interval (CI). For continuous data, means and their standard deviations were recorded for each arm of the study and results expressed as weighted mean difference (WMD) with 95\% CI. Where only the median was reported, the mean was assumed to be equal to median (after checking for skewness) and the standard deviation was estimated from the range (range $\times 0.95 / 4$ ).

We assessed heterogeneity between studies by graphical inspection of results and, more formally by, the chi-squared test of homogeneity. In the absence of significant statistical heterogeneity between studies $(P>0.1)$ were pooled their results using a fixed effects method. When there was significant heterogeneity between study results, the random effects method was used and the source of heterogeneity investigated.

\section{Results}

\section{Description of studies}

Thirty potentially eligible studies were identified, from which three were excluded because further investigation revealed that the studies were not criterion-based audit, ${ }^{4-6}$ two because the studies involved only one audit without a repeat audit or a comparison group, ${ }^{7,8}$ and two because they involved abortion/miscarriage. , $^{9,10}$

The remaining 23 studies (one RCT and 22 beforeand-after studies) with 33,911 participants met our inclusion criteria: seven audits on Cesarean section, ${ }^{11-17}$ one audit on the management of different emergency obstetric complications (obstetric hemorrhage, uterine rupture, obstructed labor and genital tract sepsis), ${ }^{18}$ four audits on the management of pre-eclampsia/eclampsia, ${ }^{19-22}$ one audit on the management of obstructed labor, ${ }^{23}$ one audit on the management of postpartum hemorrhage, ${ }^{24}$ one audit to improve a district referral system for maternity care, ${ }^{25}$ one audit to improve womenfriendly care, ${ }^{26}$ one audit on induction of labor, ${ }^{27}$ one audit on the management of third degree perineal tear, ${ }^{28}$ one audit on external cephalic version for breach presentation, ${ }^{29}$ one audit to improve return rate of pregnancy hand-held record, ${ }^{30}$ one audit on antenatal corticosteroid to enhance lung fetal maturity, ${ }^{31}$ one audit on intraparum group B streptococcus prophylaxis, ${ }^{32}$ and one audit to improve early diagnosis and treatment of complications during pregnancy. ${ }^{33}$ 
Further details about the study design, sample size, type of feedback and outcomes are presented in Table 1. There were 22 studies on criterion-based audit to improve the quality from midwives/doctors' perspective and one published study on the use of audit to improve the quality from the women/mothers' perspective. There was no study that compared the effectiveness of different types of feedback in criterion-based audit. In $35 \%(8 / 23)$ of studies the method of feedback was unclear and in $74 \%(17 / 23)$ of studies the method of feedback was educational meeting either alone or with another feedback method. Ninety six percent $(22 / 23)$ of studies showed significant improvement in at least one standard measured. The method of feedback was unclear in the study which showed no significant improvement in at least one standard measured. ${ }^{32}$ There was a significant improvement in at least one standard measured in all studies (100.0\%) in which feedback involved educational meetings either alone or with another feedback method. Seven out of eight studies $(87.5 \%)$ in which the feedback was unclear showed a significant improvement in at least one standard measured. There were no clear differences between studies that used educational meetings alone and those that combined educational meetings with other feedback methods such as written materials and posters.

In three studies new guidelines were introduced between the initial audit and the re-audit in order to improve the effectiveness of the criterion-based audit. ${ }^{13,14,28}$

\section{Summary of findings}

Table 2 presents the summary of findings of the studies included in this review.

\section{Antenatal care}

Audit of antenatal care (one study with 356 participants) improved documentation of fetal presentation (OR 1.99, 95\% CI: 1.12-3.56), and second trimester screening for anemia (OR 0.52, 95\% CI: 0.29-0.93), but did not improve documentation of the expected date of delivery (OR 1.04, 95\% CI: 0.09-11.62), fetal heart rate (OR 1.52, 95\% CI: $0.78-3.00$ ) as well as screening for diabetes (OR 0.84, 95\% CI: $0.51-1.40)$ and urinary tract infection (OR 1.70, 95\% CI: $0.71-4.11) .{ }^{33}$ Audit and feedback increased the return rate of pregnancy handheld record at time of admission for labor and birth but the effect was not significant (one study with 1096 participants: OR 1.70, 95\% CI: 0.90-3.03). ${ }^{30}$

\section{Peripartum care}

Criterion-based audit improved the number of complete steroid courses (two doses) to enhance fetal lung maturity but the effect was not significant (one study with 299 participants: OR 1.59, 95\% CI: 0.86-3.01). ${ }^{31}$

Audit and feedback for breech presentation (one study with 44 participants) improved documentation of consent for external cephalic version (OR 7.20, 95\% CI: 1.32-50.00), but did not improve breech diagnosis before labor (OR 1.04, 95\% CI: 0.26-3.51), optimal offer rate of external cephalic version (OR 1.00, 95\% CI: 0.49-2.09) and success rate for external cephalic version (OR 2.53, 95\% CI: $0.53-11.11){ }^{29}$

Audit equally showed that cervical preparation prior to late surgical termination of pregnancy using two or three Dilapan dilators (FEMA International, Kendall Park, NJ, USA) on the day before the procedure, was more effective than one or two Dilapan dilators with or without misoprostol, on the day of the procedure (one study with 137 participants: OR 3.50, 95\% CI: $1.29-10.32$ ) or day before the procedure (OR 9.25, 95\% CI: 2.74-40.58). ${ }^{27}$

Criterion-based audit did not improve adherence to intrapartum group B streptococcus prophylaxis protocol (one study with 86 participants: OR $1.56,95 \%$ CI: $0.64-3.81) .{ }^{32}$

Criterion-based audit improved the clinical management of third degree perineal tears (one study with 74 participants): repairs performed in the theatre (OR 12.16, 95\% CI: 1.50-98.92), with adequate anesthesia (12.16, 95\% CI: 1.50-98.92), using Prolene (OR 8.00, 95\% CI: 1.68-38.09), but did not improve completion of follow-up (OR 2.07, 95\% CI: $0.70-6.16){ }^{28}$

\section{Emergency obstetric complications}

Criterion-based audit improved the clinical management of severe preeclampsia/eclampsia with regards to the blood pressure monitoring ( 3 studies with 384 participants: OR 2.05, 95\% CI: 1.32-3.20 $)^{18,21,22}$ and monitoring of tendon reflexes when on magnesium sulphate (1 study with 49 participants: OR 9.21, 95\% CI: $2.18-38.86),{ }^{18}$ but did not improve the administration of magnesium sulphate to prevent seizures (three studies with 72 participants: OR 4.02, 95\% CI: $0.91-17.80),{ }^{1821,22}$ mean time for magnesium sulphate to reach therapeutic concentrations (two studies with 32 participants: WMD -2.06, 95\% CI: -5.60-1.48) $[19,20]$, review of patient by a senior staff (three studies with 424 participants: OR 2.15, 95\% CI: 0.92-5.05), ${ }^{18,21,22}$ antihypertensives for severe hypertension (one study with 36 participants: OR 0.55, 95\% CI: $0.03-9.52),{ }^{18}$ adherence to guidelines (two studies with 306 participants: OR 2.68, 95\% CI: 0.33-21.77), ${ }^{20,21}$ fluid balance documentation (two studies with 335 participants: OR 1.51, 95\% CI: 0.95-2.39), ${ }^{18,21}$ 
Table I Characteristics of studies included in the review

\begin{tabular}{|c|c|c|c|c|c|}
\hline Study & Sample & Design & Feedback & Targeted behavior & Outcomes \\
\hline Lomas" & 2496 & RCT & $\begin{array}{l}\text { Audit (educational } \\
\text { meetings); opinion } \\
\text { leaders (written } \\
\text { materials + educational } \\
\text { meetings); and control } \\
\text { group (written materials) }\end{array}$ & $\begin{array}{l}\text { Reducing Cesarean section } \\
\text { (CS) rate among women } \\
\text { with previous CS }\end{array}$ & $\begin{array}{l}\text { \% women who underwent a trial of } \\
\text { scar, \% vaginal birth, \% elective CS, } \\
\% \text { unscheduled CS, uterine dehiscence, } \\
\text { uterine rupture, stillbirths, low Apgar } \\
\text { score }(<7) \text {, duration of hospital stay }\end{array}$ \\
\hline Kiwanuka $^{12}$ & 4111 & $\begin{array}{l}\text { Before } \\
\text { and after }\end{array}$ & Educational meetings & Reducing CS rate & Indications of CS, rates of CS \\
\hline Robson ${ }^{13}$ & 21,125 & $\begin{array}{l}\text { Before } \\
\text { and after }\end{array}$ & $\begin{array}{l}\text { Educational meetings } \\
\text { and written materials }\end{array}$ & Reducing CS rate & Rates of CS \\
\hline Taylor $^{14}$ & 526 & $\begin{array}{l}\text { Before } \\
\text { and after }\end{array}$ & Unclear & $\begin{array}{l}\text { Reducing wound infection } \\
\text { by antibiotics administra- } \\
\text { tion at CS }\end{array}$ & Wound infection rate \\
\hline Bruce $^{15}$ & 378 & $\begin{array}{l}\text { Before } \\
\text { and after }\end{array}$ & $\begin{array}{l}\text { Educational meetings } \\
\text { and posters }\end{array}$ & Quality of emergency CS & $\begin{array}{l}\text { Reasons for emergency CS, decision to } \\
\text { delivery times, reasons for delay, fetal blood } \\
\text { sampling and cord } \mathrm{pH} \text { measurements, } \\
\text { ranitidine prescription, thromboprophylaxis } \\
\text { when indicated }\end{array}$ \\
\hline Nicoll $^{16}$ & 619 & $\begin{array}{l}\text { Before } \\
\text { and after }\end{array}$ & Educational meetings & Timing of elective CS & $\begin{array}{l}\text { Admission for neonatal respiratory } \\
\text { morbidity }\end{array}$ \\
\hline Nicopoullos ${ }^{17}$ & 274 & $\begin{array}{l}\text { Before } \\
\text { and after }\end{array}$ & Unclear & $\begin{array}{l}\text { Improving quality } \\
\text { of CS documentation }\end{array}$ & $\begin{array}{l}\text { Indication, name of surgeon, grade of } \\
\text { surgeon, name of assistant, name of } \\
\text { anesthetist, type of anesthetic, skin incision } \\
\text { time, skin incision type, surgical findings, } \\
\text { uterine incision type, engagement of pre- } \\
\text { senting part, fetal delivery, placenta delivery, } \\
\text { uterine cavity check, presence of pediatri- } \\
\text { cian, adnexal check, estimate of blood loss, } \\
\text { post-op care plan }\end{array}$ \\
\hline Wagaarachchi ${ }^{18}$ & 889 & $\begin{array}{l}\text { Before } \\
\text { and after }\end{array}$ & Educational meetings & $\begin{array}{l}\text { Management of emergency } \\
\text { obstetric complications }\end{array}$ & $\begin{array}{l}\text { Several outcomes on the management } \\
\text { of obstetric hemorrhage, uterine } \\
\text { rupture, obstructed labor, genital tract } \\
\text { complications and all emergency obstetric } \\
\text { complications }\end{array}$ \\
\hline Taylor $^{19}$ & 16 & $\begin{array}{l}\text { Before } \\
\text { and after }\end{array}$ & Unclear & $\begin{array}{l}\text { Management of eclampsia } \\
\text { with magnesium sulphate }\end{array}$ & $\begin{array}{l}\text { Median time to reach therapeutic } \\
\text { concentrations, clinical monitoring of } \\
\text { magnesium levels }\end{array}$ \\
\hline Owen ${ }^{20}$ & 16 & $\begin{array}{l}\text { Before } \\
\text { and after }\end{array}$ & $\begin{array}{l}\text { Printed materials and } \\
\text { educational meetings }\end{array}$ & $\begin{array}{l}\text { Management of eclampsia } \\
\text { with magnesium sulphate }\end{array}$ & $\begin{array}{l}\text { Time to reach therapeutic magnesium } \\
\text { concentrations, protocol violations }\end{array}$ \\
\hline Baldwin ${ }^{21}$ & 294 & $\begin{array}{l}\text { Before } \\
\text { and after }\end{array}$ & $\begin{array}{l}\text { Written materials and } \\
\text { educational meetings }\end{array}$ & $\begin{array}{l}\text { Management of hyperten- } \\
\text { sive illness in pregnancy }\end{array}$ & $\begin{array}{l}\text { Monitoring, fluid balance documentation, } \\
\text { fluid management, seen by a consultant } \\
\text { obstetrician, seen by member of specialist } \\
\text { team, adherences to guidelines, magnesuim } \\
\text { sulphate as treatment for eclampsia }\end{array}$ \\
\hline Weeks 22 & 86 & $\begin{array}{l}\text { Before } \\
\text { and after }\end{array}$ & Educational meetings & $\begin{array}{l}\text { Management of severe } \\
\text { pre-eclampsia }\end{array}$ & $\begin{array}{l}\text { Time from admission to doctors' attendance } \\
(<1 \text { hour), initiation of drug treatment } \\
(<20 \text { minutes), magnesium sulphate given, } \\
\text { urinalysis done, specialist review, blood pres- } \\
\text { sure monitored, fetal heart rate monitored, } \\
\text { blood test done and steroids given }\end{array}$ \\
\hline Kongnyuy ${ }^{25}$ & 85 & $\begin{array}{l}\text { Before } \\
\text { and after }\end{array}$ & Educational meetings & $\begin{array}{l}\text { Management of obstructed } \\
\text { labor }\end{array}$ & $\begin{array}{l}\text { IV line set up and patient hydrated, typing } \\
\text { and cross-match of blood, urinary bladder } \\
\text { drained, initiation of CS }(<\text { I hour) or } \\
\text { delivery ( }<2 \text { hour), antibiotics adminis- } \\
\text { tered, observation chart maintained }\end{array}$ \\
\hline
\end{tabular}

(Continued) 
Table I (Continued)

\begin{tabular}{|c|c|c|c|c|c|}
\hline Study & Sample & Design & Feedback & Targeted behavior & Outcomes \\
\hline Kongnyuy ${ }^{26}$ & 85 & $\begin{array}{l}\text { Before } \\
\text { and after }\end{array}$ & Educational meetings & $\begin{array}{l}\text { Management of postpartum } \\
\text { hemorrhage }\end{array}$ & $\begin{array}{l}\text { Intravenous (IV) line set up and IV fluids } \\
\text { administered, typing and cross-match of } \\
\text { blood, hemoglobin or hematocrit done, } \\
\text { monitoring of vital signs, fluids intake/ } \\
\text { output chart maintained, administration } \\
\text { of oxytocics }\end{array}$ \\
\hline Kongnyuy ${ }^{27}$ & 122 & $\begin{array}{l}\text { Before } \\
\text { and after }\end{array}$ & Educational meetings & $\begin{array}{l}\text { Referral system for } \\
\text { maternity care }\end{array}$ & $\begin{array}{l}\text { Patients are referred with a filled referral } \\
\text { form, ambulance available } 24 \text { hours/day } \\
\text { and seven days/week, referral hospital } \\
\text { informed when patient is referred, } \\
\text { feedback for all patients referred, adequate } \\
\text { resuscitation before referral, time lapse } \\
\text { between calling an ambulance and arriving } \\
\text { with a patient in hospital }<2 \text { hours, } \\
\text { patients attended to within } 30 \text { minutes of } \\
\text { arrival to hospital }\end{array}$ \\
\hline Kongnyuy ${ }^{28}$ & 647 & $\begin{array}{l}\text { Before } \\
\text { and after }\end{array}$ & Educational meetings & Women-friendly care & $\begin{array}{l}\text { Greeting of women by providers, } \\
\text { self-introduction by providers, privacy, } \\
\text { confidentiality, cleanliness of maternity, } \\
\text { companion allowed during labor and } \\
\text { delivery, women allowed to adopt the } \\
\text { position of their choice during delivery, } \\
\text { women treated with dignity and respect, } \\
\text { use of simple language by providers, } \\
\text { women satisfaction with the care received }\end{array}$ \\
\hline Poon ${ }^{29}$ & 137 & $\begin{array}{l}\text { Before } \\
\text { and after }\end{array}$ & Unclear & $\begin{array}{l}\text { Cervical preparation with } \\
\text { Dilapan dilators prior to } \\
\text { late } 2 \text { nd trimester surgical } \\
\text { termination of pregnancy }\end{array}$ & Need for further cervical dilatation \\
\hline Williams ${ }^{30}$ & 124 & $\begin{array}{l}\text { Before } \\
\text { and after }\end{array}$ & Unclear & $\begin{array}{l}\text { Management of 3rd degree } \\
\text { perineal tears }\end{array}$ & $\begin{array}{l}\text { Fecal symptoms, urinary symptoms, } \\
\text { dysparuenia, prolene migration, } \\
\text { refashioning of perineum }\end{array}$ \\
\hline Siassakos ${ }^{31}$ & 44 & $\begin{array}{l}\text { Before } \\
\text { and after }\end{array}$ & Educational meetings & $\begin{array}{l}\text { External cephalic version } \\
\text { for breech presentation }\end{array}$ & $\begin{array}{l}\text { External cephalic version (ECV) offered, } \\
\text { ECV declined, ECV successful, consent } \\
\text { form filed in case notes, cardiotocography } \\
\text { abnormality, emergency CS necessitated, } \\
\text { formal obstetric scan prior to ECV }\end{array}$ \\
\hline Toohill ${ }^{32}$ & 1096 & $\begin{array}{l}\text { Before } \\
\text { and after }\end{array}$ & Unclear & $\begin{array}{l}\text { Improving return rate } \\
\text { of pregnancy hand-held } \\
\text { record }\end{array}$ & $\begin{array}{l}\% \text { pregnancy hand-held records retrieved } \\
\text { at the time of admission to birth suites }\end{array}$ \\
\hline Khoo $^{33}$ & 299 & $\begin{array}{l}\text { Before } \\
\text { and after }\end{array}$ & $\begin{array}{l}\text { Written materials and } \\
\text { educational meetings }\end{array}$ & $\begin{array}{l}\text { Antenatal corticosteroid to } \\
\text { enhance lung maturity }\end{array}$ & $\begin{array}{l}\% \text { deliveries between } 24 \text { and } 36 \text { weeks that } \\
\text { received two courses of steroid, \% cases } \\
\text { in which senior opinion was sought when } \\
\text { repeat courses of steroid was contem- } \\
\text { plated, frequency of steroid courses per } \\
\text { delivery, \% potentially effective steroid } \\
\text { courses }\end{array}$ \\
\hline $\mathrm{McCord}^{34}$ & 86 & $\begin{array}{l}\text { Before } \\
\text { and after }\end{array}$ & Unclear & $\begin{array}{l}\text { Intrapartum group B } \\
\text { streptococcus prophylaxis }\end{array}$ & $\begin{array}{l}\text { \% women with risk factors given group B } \\
\text { streptococcus prophylaxis }\end{array}$ \\
\hline Bailón ${ }^{35}$ & 356 & $\begin{array}{l}\text { Before } \\
\text { and after }\end{array}$ & Unclear & Antenatal care & $\begin{array}{l}\text { Clinical history, clinical examination, } \\
\text { and early detection and treatment of } \\
\text { complications such as of diabetes, urinary } \\
\text { tract infection, anemia, hypertension, } \\
\text { hepatitis B }\end{array}$ \\
\hline
\end{tabular}


Table 2 Summary of findings of the studies included in the review

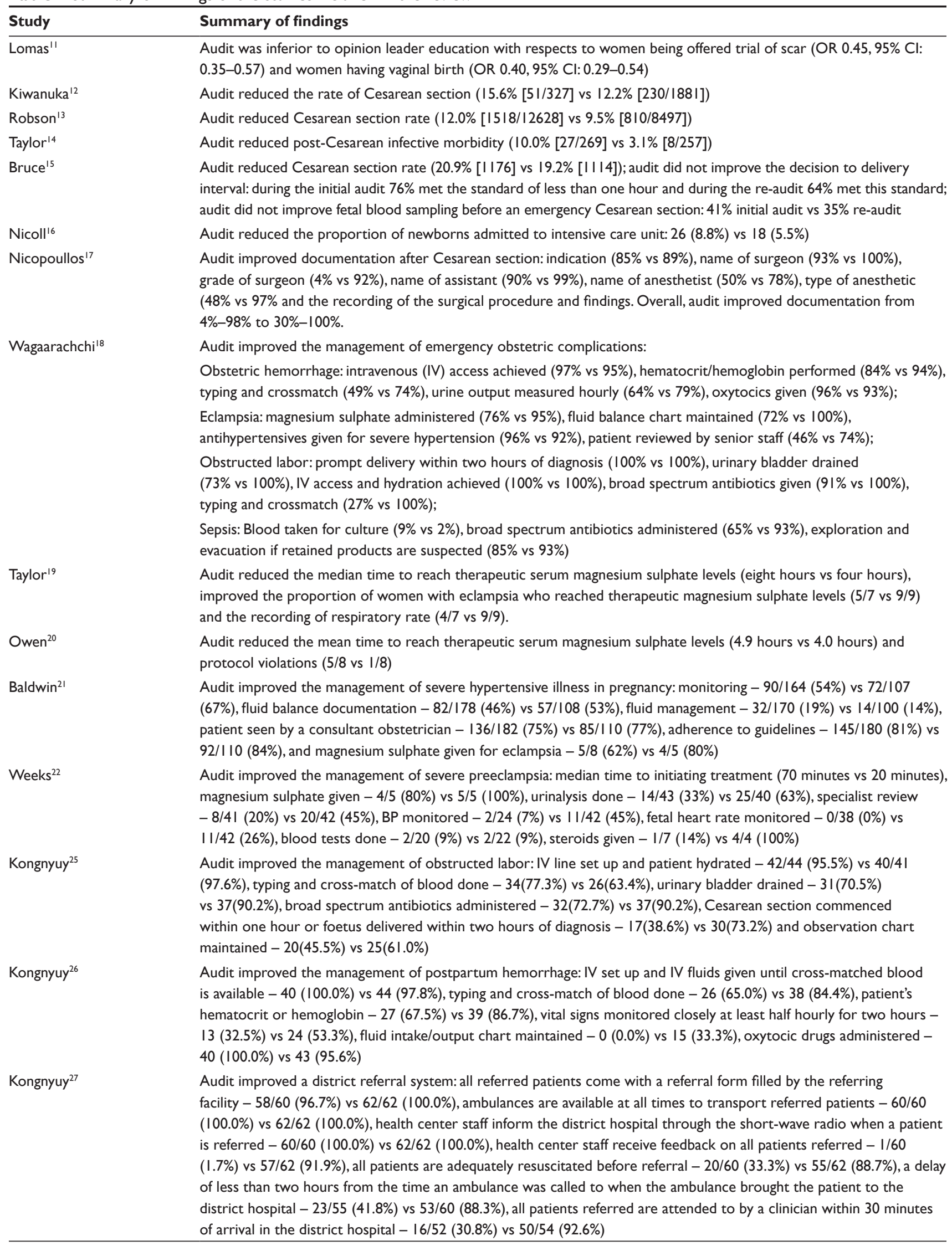


Table 2 (Continued)

\begin{tabular}{|c|c|}
\hline Study & Summary of findings \\
\hline Kongnyuy ${ }^{28}$ & 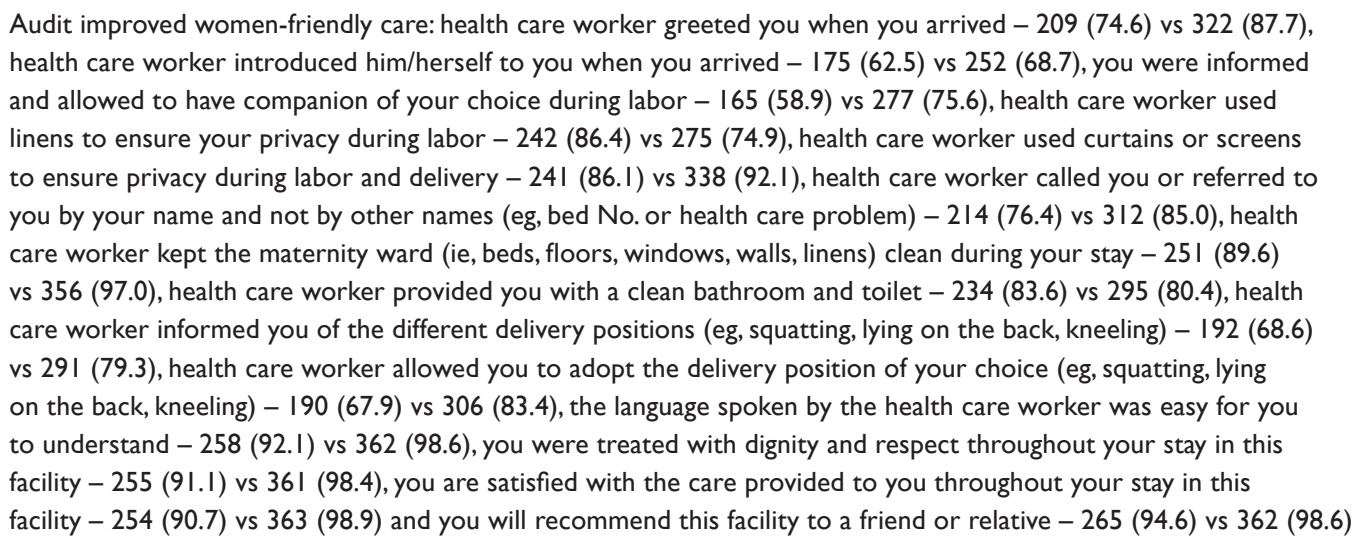 \\
\hline Poon $^{29}$ & $\begin{array}{l}\text { Audit showed that cervical preparation prior to late surgical termination of pregnancy using two or three Dilapan } \\
\text { dilatorsal, on the day before the procedure was more effective than one or two Dilapan dilators with or without } \\
\text { misoprostol, on the day of the procedure (OR } 3.50,95 \% \mathrm{Cl} \text { । I.29-10.32) or day before the procedure (OR } 9.25,95 \% \\
\mathrm{Cl}: 2.74-40.58)\end{array}$ \\
\hline Williams $s^{30}$ & $\begin{array}{l}\text { Audit improved the clinical management of third degree perineal tears: repairs performed in the theatre (OR I2.16, } \\
95 \% \mathrm{Cl} \text { : I.50-98.92), with adequate anesthesia (I2.16,95\% Cl: I.50-98.92), using Prolene (OR 8.00,95\% Cl: I.68-38.09), } \\
\text { but did not improve completion of follow-up (OR } 2.07,95 \% \mathrm{Cl}: 0.70-6.16)\end{array}$ \\
\hline Siassakos ${ }^{31}$ & $\begin{array}{l}\text { Audit improved documentation of consent for external cephalic version for breech presentation (OR } 7.20,95 \% \\
\mathrm{Cl} \text { : I.32-50.00), but did not improve breech diagnosis before labor (OR I.04, } 95 \% \mathrm{Cl}: 0.26-3.5 \mathrm{I}) \text {, optimal offer rate of } \\
\text { external cephalic version (OR I.00, } 95 \% \mathrm{Cl}: 0.49-2.09) \text { and success rate for external cephalic version (OR } 2.53,95 \% \\
\mathrm{Cl}: 0.53-\text { II.II) }\end{array}$ \\
\hline Toohill ${ }^{32}$ & $\begin{array}{l}\text { Audit increased the return rate of pregnancy handheld record at time of admission for labor and birth but the effect } \\
\text { was not statistically significant (OR } 1.70,95 \% \mathrm{Cl}: 0.90-3.03)\end{array}$ \\
\hline $\mathrm{Khoo}^{33}$ & $\begin{array}{l}\text { Audit improved the number of complete steroid courses (two doses) to enhance fetal lung maturity but the effect was } \\
\text { not statistically significant (OR I.59, } 95 \% \mathrm{Cl}: 0.86-3.01)\end{array}$ \\
\hline McCord ${ }^{34}$ & Audit did not improve adherence to intrapartum group B streptococcus prophylaxis protocol (OR I.56, 95\% Cl: $0.64-3.8 \mathrm{I})$ \\
\hline Bailón ${ }^{35}$ & $\begin{array}{l}\text { Audit of antenatal care improved documentation of fetal presentation (OR I.99, } 95 \% \mathrm{Cl} \text { : I.I2-3.56), and second } \\
\text { trimester screening for anemia (OR } 0.52,95 \% \mathrm{Cl}: 0.29-0.93) \text {, but did not improve documentation of the expected date } \\
\text { of delivery (OR I.04, } 95 \% \mathrm{Cl}: 0.09-\mathrm{II} .62 \text { ), fetal heart rate (OR I.52, } 95 \% \mathrm{Cl}: 0.78-3.00 \text { ) as well as screening for diabetes } \\
\text { (OR } 0.84,95 \% \mathrm{Cl}: 0.5 \mathrm{I}-\mathrm{I} .40 \text { ) and urinary tract infection (OR I.70, } 95 \% \mathrm{Cl}: 0.7 \mathrm{I}-4.1 \mathrm{I})\end{array}$ \\
\hline
\end{tabular}

Abbreviations: $\mathrm{Cl}$, confidence interval; OR, odds ratio.

and testing of blood (two studies with 91 participants: OR 1.52, 95\% CI: 0.55-4.16). ${ }^{18,22}$ Figure 1 presents the effect of criterion-based audit on blood pressure monitoring in women with severe pre-eclampsia/eclampsia.

Criterion-based audit equally improved the clinical management of obstetric hemorrhage (2 studies with 770 participants) with regards to testing of hematocrit or hemoglobin (OR 3.07, 95\% CI: 1.84-5.14), typing and crossmatch (OR 2.96, 95\% CI: 2.15-4.09), and measurement of urine output (OR 2.41, 95\% CI: 1.70-3.42), but there was no significant change in intravenous access (OR $0.55,95 \% \mathrm{CI}$ : 0.26-1.18), continuous infusion of crystalloids and/or colloids until cross-matched blood was available (OR 0.55, 95\% CI: 0.26-1.18), and administration of oxytocics for primary postpartum hemorrhage (OR $0.50,95 \%$ CI: $0.26-0.96) .^{18,24}$
Audit and feedback brought about a significant change in the clinical management of obstructed labor (two studies with 100 participants) with respect to the drainage of urinary bladder (OR 3.85, 95\% CI: 1.23-12.04) and maintaining an observation chart (OR 7.00,95\% CI: 2.46-21.11), but not the administration of broad spectrum antibiotics (OR 3.10, 95\% CI: 0.98-9.81) and typing and crossmatch (OR 0.89, 95\% CI: 0.38-1.98)..$^{18,23}$

Audit and feedback improved the administration of broad spectrum antibiotics for genital tract sepsis (one study with 123 participants: OR 6.95, 95\% CI: 2.24-21.59), but did not improve the blood specimen taken for culture (OR 0.19, 95\% CI: $0.02-1.64)$ and exploration and evacuation if retained products of conception are suspected (OR 2.20, 95\% CI: $0.65-7.44) .{ }^{18}$ 


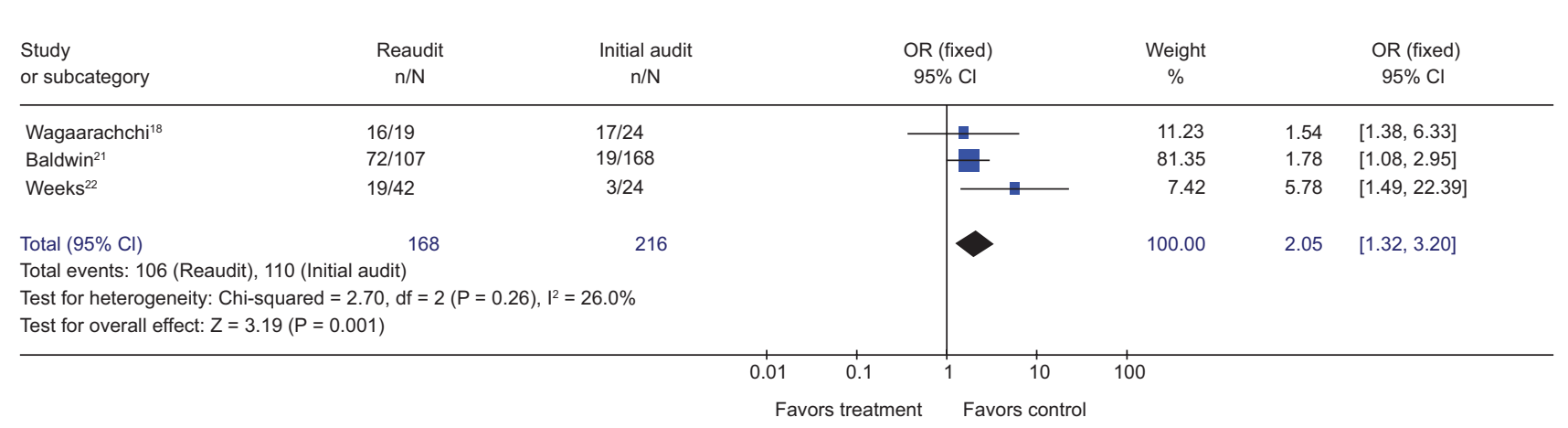

Figure I Effect of criterion-based audit on proper monitoring of blood pressure in women with severe pre-elampsia/eclampsia.

Audit improved the handling of obstetric emergencies by a district referral system (one study with 122 participants) with respect to adequate resuscitation before referral (OR 2.66, 95\% CI: 1.43-5.01), delay of less than two hours from the time the ambulance is called to when the ambulance brought the patient to the hospital (OR 2.11, 95\% CI: 1.15-3.92), clinicians attending to patient within 30 minutes of arrival to the hospital (OR 3.01, 95\% CI: 1.53-6.03), feedback given to the referring health centers (OR 55.16, 95\% CI: 10.08-1138.11), but did not improve the availability of ambulances at all times (OR 1.00, 95\% CI: 0.59-1.70), referral of all patients with a completed referral form (OR 1.03, 95\% CI: 0.61-1.77), and referral hospital informed when a patient is referred (OR 1.00, 95\% CI: $0.59-1.70) .{ }^{25}$

\section{Cesarean section}

Criterion-based audit reduced Cesarean section rate (three studies with 27,732 participants: OR $0.82,95 \% \mathrm{CI}$ : 0.73-0.92) $)^{11-13}$ and improved documentation of Cesarean section (1 study with 274 participants): type of anesthetic (OR 48.09, 95\% CI: 16.81-137.62), type of uterine incision (OR 28.86, 95\% CI: 6.81-122.07), surgical findings (OR 50.32, 95\% CI: 6.79-372.93), but not the indication for Cesarean section (OR 1.39, 95\% CI: 0.68-2.84). ${ }^{17}$ There was significant heterogeneity $(p=0.04)$ between studies that assessed the effect of audit on Cesarean section rate, presumably due to differences in the type of feedback and recommendations implemented to reduce Cesarean section rate. Figure 2 presents the effect of criterion-based audit on Cesarean section rate.

Criterion-based audit to improve the timing of elective Cesarean section did not reduce admissions for neonatal respiratory morbidity (one study with 619 participants: OR 0.60, 95\% CI: 0.32-1.11) ${ }^{16}$ and audit of emergency Cesarean section did not significantly improve the decision-to-delivery time (one study with 378 participants: OR $1.73,95 \%$ CI: $0.98-3.04) .{ }^{15}$ Criterion-based audit however improved antibiotic prophylaxis during Cesarean section (one study with 526 participants: OR 31.47, 95\% CI: 14.31-69.22) and reduced wound infection rate (OR $0.29,95 \%$ CI: $0.13-0.65){ }^{14}$

Lomas and colleagues compared the effectiveness of criterion-based audit with education given to physicians by opinion leaders. ${ }^{11}$ Opinions leaders were senior obstetricians who were highly respected by their fellow colleagues. Compared to participants in opinion leader education intervention, participants in criterion-based audit group were less likely to be offered trial of scar (one randomized controlled trial with 1263 participants: OR $0.45,95 \%$ CI: $0.35-0.57$ ) and to have vaginal birth (OR $0.40,95 \%$ CI: $0.29-0.54) .{ }^{11}$

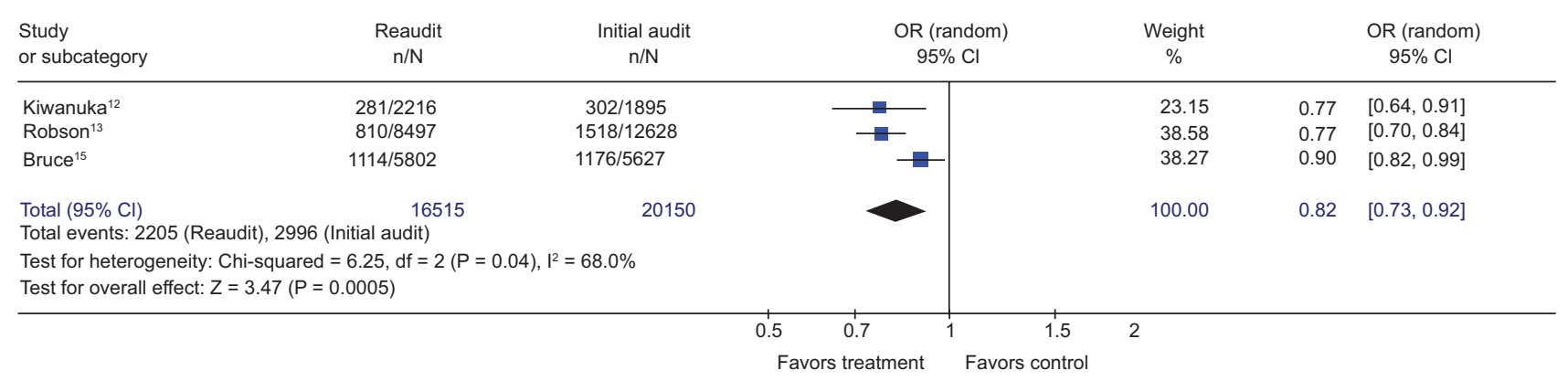

Figure 2 Effect of criterion-based audit on Cesarean section rates. 


\section{Women-friendly care}

Audit let to significant improvements in women-friendly care (one study with 647 participants): greeting clients (OR 2.43, 95\% CI: 1.61-3.70), respect of clients (OR 5.90, 2.47-15.93), support by a companion during labor (OR 2.15, 95\% 1.54-3.03), women allowed to have companion during labor (OR 2.15, 95\% CI: 1.54-3.03), informing clients about different birthing positions (OR 1.75, 95\% CI: 1.22-2.50), allowing clients to adopt different birthing positions (OR 2.38, 95\% CI: 1.64-3.45), cleanliness of maternity wards (OR 3.74, 95\% CI: 1.86-7.92), speaking to women using simple language (OR 6.17, 95\% CI: 2.41-18.48) and ensuring privacy with curtains or screens (OR 1.89, 95\% CI: 1.14-3.13). ${ }^{26}$ However, audit did not improve selfintroduction by providers (OR 1.31, 95\% CI: 0.95-1.82), and provision of a clean bathroom and toilet (OR 0.81, 95\% CI: $0.53-1.21){ }^{26}$

\section{Discussion}

\section{Main findings}

This review explored the use of criterion-based clinical audit in obstetrics and its effects on obstetric practice. Both randomized controlled trials and studies with before-and-after design were included. A total of 23 studies (including one RCT) met our eligibility criteria and were included in this review. Ninety-six percent (22/23) of studies assessed the effectiveness of audit to improve obstetric care from the doctors/midwives' view while 4\% (1/23) assessed the effect of audit from mothers/women's view.

The effects of criterion-based audit on obstetric practice varied from an apparently negative effect to very large positive effect. Where significant, the effect was found to be generally small to moderate. The effect of criterionbased clinical audit was likely to be significant if baseline adherence was poor and the sample size was adequate. The findings of this study are similar to those reported previously on the effect of audit and feedback on professional practice and health outcomes. ${ }^{1}$ The authors found that the effect of audit and feedback on desired practice varied from $16 \%$ absolute decrease in compliance to $70 \%$ increase in compliance.

The extent to which criterion-based audit influences clinical practice depends on the characteristics of feedback such as the message, the provider of the feedback, the addressee, the timeliness and the vehicle. ${ }^{34}$ Passive provision of information, such as the dissemination of printed materials, posters and didactic lectures, results to little if any change in practice, ${ }^{1,35}$ while active feedback such as interactive workshops and interactive educational meetings are likely to be beneficial. ${ }^{35}$

There are many plausible explanations of why some criterion-based audits are effective in changing practice why others are not. Factors associated with the effectiveness of criterion-based audit can be traced from the five steps of a clinical audit cycle. Step 1 - establish criteria of good practice: "who establish the criteria?", "are they evidence-based?, "are they achievable within the resource constraints?". If criteria or standards are not achievable, not evidence-based or people implementing them are not consulted during the standards setting process, criterion-based audit is unlikely to improve the quality of obstetric practice. ${ }^{36}$ Step 2 - measuring current practice: "is there selection bias and/or measurement bias?". Step 3 - feedback findings and set local targets: "what are the gaps identified in current practice?", "what is the method of feedback?" and "what are the recommendations made to address problems identified?". Step 4 - implement changes in practice where indicated: "how successful were the recommendations implemented?". Step 5 - re-evaluate practice and feedback: like in step 2, selection and measurement biases might be introduced at this stage. In the current review, it was noted that only few studies clearly stated these five steps in the methodology. In eight out of 23 studies the method of feedback was not clearly stated.

In the past two decades the focus of criterion-based clinical audit in obstetrics has been to improve the management of emergency obstetric complications, which is justified because about $80 \%$ maternal deaths occur as a result of these complications..$^{37}$ Few studies have assessed the effect of audit and feedback on antenatal and/or postnatal care, and no published studies have assessed the effect of criterion-based audit on women/mothers satisfaction and perception of health care. There are two dimensions of quality of obstetric care, namely quality of health outcomes and quality as experienced by women receiving the care. ${ }^{38}$ Both dimensions are crucial in measuring and improving the quality of care which in turn affects utilization of maternal and newborn health services.

The only RCT included in this review found that physicians in hospitals receiving an opinion leader education intervention were less likely to perform inappropriate Cesarean section than physicians in control hospitals and hospitals receiving criterion-based audit. ${ }^{11}$ However, the results of this study are difficult to interpret because opinion leaders received $1 \frac{1}{2}$ days of intense training in guidelines for performing Cesarean section and this type of training was not given to any other physician in the study. In their analysis, they combined cases managed by the four opinion leaders 
with those handled by the other 15 physicians in the opinion leader education group, and did not specify the proportion of cases handled by the four opinion leaders. Thus we cannot conclude from this study that opinion leader education is better than criterion-based audit.

\section{Strengths and limitations of the evidence and review}

We found only one RCT that assessed the use of criterionbased audit to improve quality of obstetric care from both the midwives/doctors' and women/mothers' perspectives. Properly conducted RCTs are regarded as the best method of assessing the effectiveness of health care interventions as they generate comparable intervention and nonintervention groups with the only differences between the groups being attributable to the effect of the intervention, or chance. ${ }^{39}$ Many studies lacked the adequate sample size to show a significant change in clinical practice. Many studies were excluded because they did not complete the clinical audit cycle. Studies with before and after design are useful in monitoring and improving clinical practice, but it is difficult to attribute causation based on before-and-after studies. The primary role of before-and-after studies is clinical governance defined as "a framework through which health organizations are accountable for continuously improving the quality of their services and safeguarding high standards of care, by creating an environment in which excellence in clinical care will flourish". ${ }^{40}$ The results of this review are likely to be affected by publication bias since studies with negative findings are less likely to be published compared to studies with positive findings.

\section{Conclusions}

In conclusion, clinical audit leads to moderate improvements in obstetric care from both the health professionals' and mothers/clients' perspectives especially if baseline adherence is poor. Audit can be a useful tool to measure, improve and monitor the quality of day-to-day obstetric practice. Priority should be given to those practices where baseline adherence is known or suspected to be poor. Midwives and doctors working in maternity units should consider the use of audit to improve quality of care from the women/mothers' view. Attempts should be made wherever possible to complete the audit cycle. Better reporting on how standards are established, how baseline measurements are performed, type of feedback, targeted behavior and characteristic of study participants is needed. There is need for well designed randomized controlled trials to assess the effectiveness of different types of feedback in criterion-based audit.

\section{Acknowledgments}

The Liverpool School of Tropical Medicine (UK) provided internal support for this review. We wish to thank Dr Uthman for his comments on an earlier version of this review. The authors report no conflicts of interest in this work.

\section{References}

1. Jamtvedt G, Young JM, Kristoffersen DT, O'Brien MA, Oxman AD. Audit and feedback: effects on professional practice and health care outcomes. Cochrane Database Syst Rev. 2006;(2):CD000259.

2. World Health Organization. Beyond the Numbers: Reviewing Maternal Deaths and Complications to Make Pregnancy Safer. Geneva, Switzerland: Department of Reproductive Health and Research, WHO; 2004.

3. National Institute for Clinical Excellence. Principles for Best Practice in Clinical Audit. Abingdon, UK: Radcliffe Medical Press; 2002.

4. Filippi V, Brugha R, Browne E, Gohou V, Bacci A, De Brouwere V, et al. Obstetric audit in resource-poor settings: lessons from a multicountry project auditing 'near miss' obstetrical emergencies. Health Policy Plan. 2004;19(1):57-66.

5. Ward HR, Howarth GR, Jennings OJ, Pattinson RC. Audit incorporating avoidability and appropriate intervention can significantly decrease perinatal mortality. SAfr Med J. 1995;85(3):147-150.

6. Sandin-Bojö AK, Hall-Lord ML, Axelsson O, Larsson BW. Intrapartal care in a Swedish maternity unit after a quality-improvement programme. Midwifery. 2007;23(2):113-122.

7. Rosenberg K, Hepburn M, Mcllwaine G. An audit of caesarean section in a maternity district. Br J Obstet Gynaecol. 1982;89(10):787-92.

8. Gillies A. Improving patient care in the UK: clinical audit in the Oxford Region. Int J Qual Health Care. 1996;8(2):141-152.

9. Penney GC, Glasier A, Templeton A. Multicentre criterion based audit of the management of induced abortion in Scotland. BMJ. 1994;309(6946):15-19.

10. Tierney JP, Welsh J, Owen P. Management of early pregnancy loss - a complete audit cycle. J Obstet Gynaecol. 2006;26(3):229-232.

11. Lomas J, Enkin M, Anderson GM, Hannah WJ, Vayda E, Singer J. Opinion leaders vs audit and feedback to implement practice guidelines: delivery after previous Caesarean section. JAMA. 1991;265:2202-2207.

12. Kiwanuka AI, Moore WM. Influence of audit and feedback on use of caesarean section in a geographically-defined population. Eur J Obstet Gynecol Reprod Biol. 1993;50(1):59-64.

13. Robson MS, Scudamore IW, Walsh SM. Using the medical audit cycle to reduce Caesarean section rates. Am J Obstet Gynecol. 1996; 174(1 Pt 1):199-205.

14. Taylor GM. An audit of the implementation of guidelines to reduce wound infection following caesarean section. Health Bull (Edinb). 2000;58(1):38-44.

15. Bruce D, Stone S, Harding K. Evaluation of emergency caesarean sections - completion of the audit cycle in a Central London teaching hospital. J Obstet Gynaecol. 2002;22(3):273-278.

16. Nicoll AE, Black C, Powls A, Mackenzie F. An audit of neonatal respiratory morbidity following elective caesarean section at term. Scott Med J. 2004;49(1):22-25.

17. Nicopoullos JD, Karrar S, Gour A, Panter K. Significant improvement in quality of caesarean section documentation with dedicated operative proforma - completion of the audit cycle. JObstet Gynaecol. 2003;23(4):381-386.

18. Wagaarachchi PT, Graham WJ, Penney GC, McCaw-Binns A, Yeboah Antwi K, Hall MH. Holding up a mirror: changing obstetric practice through criterion-based clinical audit in developing countries. Int $J$ Gynaecol Obstet. 2001;74(2):119-130.

19. Taylor GM, McKenzie CA, Mires GJ. The use of audit to improve clinical effectiveness in an infrequent obstetric therapy: magnesium sulphate in severe pre-eclampsia. Scott Med J. 1998;43(5):151-153. 
20. Owen P. Audit can ensure the safe and effective introduction of seizure prophylaxis with magnesium sulphate in obstetric practice. Health Bull (Edinb). 2000;58(5):414-417.

21. Baldwin KJ, Leighton NA, Kilby MD, et al. The 'Severe Hypertensive Illness in Pregnancy' (SHIP) audit: promoting quality care using a high risk monitoring chart and eclampsia treatment pack. J Obstet Gynaecol. 2002;22(4):346-352.

22. Weeks AD, Alia G, Ononge S, Otolorin EO, Mirembe FM. A criteriabased audit of the management of severe pre-eclampsia in Kampala, Uganda. Int J Gynaecol Obstet. 2005;91(3):292-297.

23. Weeks AD, Alia G, Ononge S, Mutungi A, Otolorin EO, Mirembe FM. Introducing criteria based audit into Ugandan maternity units. Qual Saf Health Care. 2004;13(1):52-55.

24. Weeks AD, Alia G, Ononge S, Mutungi A, Otolorin EO, Mirembe FM. Introducing criteria based audit into Ugandan maternity units. BMJ. 2003;327(7427):1329-1331.

25. Kongnyuy EJ, Mlava G, van den Broek N.A criterion based audit of the management of obstructed labour in Malawi. Arch Gynecol Obstet. 2009;279(5):649-654.

26. Kongnyuy EJ, Mlava G, van den Broek N. Using criteria-based audit to improve the management of postpartum haemorrhage in resource limited countries: a case study of Malawi. Matern Child Health J. 2008; Sep 9. [Epub ahead of print].

27. Kongnyuy EJ, Mlava G, van den Broek N. Criteria-based audit to improve a district referral system in Malawi: a pilot study. BMC Health Serv Res. 2008;8:190.

28. Kongnyuy EJ, Mlava G, van den Broek N. Criteria-based audit to improve women-friendly care in maternity units in Malawi. J Obstet Gynaecol Res. 2009;35(3):483-489.

29. Poon LC, Parsons J. Audit of the effectiveness of cervical preparation with Dilapan prior to late second-trimester (20-24 weeks) surgical termination of pregnancy. BJOG. 2007;114(4):485-488.

30. Williams A, Adams EJ, Bolderson J, Tincello DG, Richmond DH Effect of a new guideline on outcome following third-degree perineal tears: results of a 3-year audit. Int Urogynecol J Pelvic Floor Dysfunct. 2003;14(6):385-389.
31. Siassakos D, Anderson H, Panter K. Breech presentation: an audit project as means of pursuing clinical excellence. J Obstet Gynaecol. 2005;25(7):642-647.

32. Toohill J, Soong B, Meldrum M. Risk management considerations and the pregnancy handheld record. An audit of the return rate of the pregnancy handheld record. Women Birth. 2006;19(4): 113-116.

33. Khoo C, Welsh J, Owen P. Antenatal corticosteroid prescribing: a complete audit cycle. J Obstet Gynaecol. 2007;27(1):33-36.

34. McCord N, Owen P, Powls A, Lunan B. A complete audit cycle of intrapartum group B streptococcus prophylaxis. Health Bull (Edinb). 2001;59(4):263-267.

35. Bailón E, Delgado A, Montoro R, Vázquez R, Sánchez MR, Alemany V. Efficacy of auditing in improving a Control Program of Pregnancy. Aten Primaria. 1992;9(2):85-88.

36. Axt-Adam $P$, van der Wouden JC, van der Does E. Influencing behavior of physicians ordering laboratory tests: a literature study. Med Care. 1993;31(9):784-794.

37. World Health Organization. Evidence-led Obstetric Care: Report of a WHO Meeting - Geneva, Switzerland, 28-30 January 2004. Geneva, Switzerland: WHO; 2005.

38. Hearnshaw H, Harker R, Cheater F, Baker R, Grimshaw G. A study of the methods used to select review criteria for clinical audit. Health Technol Assess. 2002;6(1):1-78.

39. Khan KS, Wojdyla D, Say L, Gülmezoglu AM, Van Look PF. WHO analysis of causes of maternal death: a systematic review. Lancet. 2006;367(9516):1066-1074.

40. Pittrof R, Campbell OM, Filippi VG. What is quality in maternity care? An international perspective. Acta Obstet Gynecol Scand. 2002;81:277-283.

41. Kleijnen J, Gotzsche P, Kunz RA, Oxman AD, Chalmers I. What's so special about randomisation? In: Maynard A, Chalmers I, editors. Non-random Reflections of Health Services Research. London, UK: BMJ Publishing Group; 1997. pp. 93-106.

42. Queenborough R, editor. NHS Pharmacy Audit Handbook. London, UK: National Prescribing Centre; 2000.
Clinical Audit

\section{Publish your work in this journal}

Clinical Audit is an international, peer-reviewed, open access journal focusing on the processes and outcomes of clinical audit in any area of healthcare. All aspects of patient care are addressed within the journal and practitioners from all disciplines are invited to submit their work. Areas covered include: Publication of audits; How an audit has changed practice;
Practical tips on how to do audits and to avoid pitfalls; How audits have changed patient care; Calls and justifications for new audits. The manuscript management system is completely online and includes a very quick and fair peer-review system, which is all easy to use. Visit http://www.dovepress. com/testimonials.php to read real quotes from published authors. 